\title{
An exploration of the association between fuel subsidies and fuel riots
}

Neil McCulloch

Associate Fellow, Institute of Development Studies

Davide Natalini ( $\nabla$ davide.natalini@aru.ac.uk)

Anglia Ruskin University

Naomi Hossain

American University

Patricia Justino

Institute of Development Studies

Article

Keywords: fuel riots, fuel subsidies

Posted Date: January 18th, 2021

DOl: https://doi.org/10.21203/rs.3.rs-142268/v1

License: (c) (1) This work is licensed under a Creative Commons Attribution 4.0 International License. Read Full License 


\title{
An exploration of the association between fuel subsidies and fuel riots
}

\author{
January 14, 2021
}

\begin{abstract}
Fuel riots are common around the world. Between 2005 and 2018, 41 countries had at least one riot directly associated with popular demand for fuel. We make use of a new international dataset on fuel riots to explore the effects of fuel prices and price regimes on fuel riots. In line with prior expectations, we find that large domestic fuel price shocks are a key driver of riots - as these are often linked to international price shocks. In addition, we report a novel result: fuel riots are closely associated with domestic price regimes. Countries that maintain fixed price regimes - notably net energy exporters - tend to have large fuel subsidies. When such subsidies become unsustainable, domestic price adjustments are large, often leading to riots.
\end{abstract}




\section{Introduction}

In 2019, there were major protests related to energy in Sudan, France, Zimbabwe, Haiti, Lebanon, Ecuador, Iraq, Chile, and Iran - many of which turned into riots. Energy-related riots seem also to be relatively common: in most years between 2005 and 2018, there have been riots in at least one or two countries. It is therefore surprising that there is almost no academic literature that explores the determinants of fuel riots. ${ }^{1}$. Although there is a significant literature on energy-related conflict, it tends to focus on conflict over abundance of fossil fuels (e.g. Van der Ploeg, 2011; Ross, 2004; Carbonnier \& Wagner, 2011). There is, however, evidence that conflict and unrest may be related to increases in oil prices. In a seminal paper, Dube and Vargas (2013) show that increases in the international price of oil are associated with increases in violence in Colombia in municipalities in oil-producing regions. This result is confirmed in a recent review of 350 studies by Blair, Christensen, and Rudkin (2020), who conclude that the probability of conflict is positively associated with increases in oil prices.

However, most of the existing literature focuses on armed conflict and knowledge about less violent forms of political violence (like riots) is more limited. ${ }^{2}$ Evidence on the mechanisms that may explain the association between shocks in international oil prices and conflict is also limited. This paper addresses these gaps by drawing on a unique database on fuel riots (Natalini et al., 2020) to examine in detail the association between fuel riots and price shocks. We find, as expected, a positive association between international oil prices and fuel riots. We show that this effect is associated with the domestic price regime and fuel subsidies. We find that countries that are net energy exporters are much more likely to fix domestic fuel prices to protect local populations against price rises. However, countries that fix prices tend to have much larger fuel subsidies and, when these can no longer be sustained, much bigger domestic price adjustments are needed, often leading to riots.

This is an important contribution because the existing literature on riots and civil unrest rarely takes into consideration how fluctuations in international prices of oil may be transmitted to local markets in ways that may drive citizens to riot. This transmission is not a given because several countries adopt subsidy policies to cushion local markets against fluctuations in the international price of oil. As long as these price regimes are sustainable, it is unlikely that changes in the international price of oil will affect local markets and, therefore, the probability of riots occurring. While some countries allow international prices to pass through fully to domestic prices, others fix domestic prices - at least temporarily - in an attempt to protect domestic consumers from such shocks. However, fixing prices below international prices generates fuel subsidies whose size depends on the regulated domestic price and the international price of fuel.

The propensity to use fuel subsidies to protect domestic consumers is often linked to the structure of the economy. Fuel exporters are particularly likely to have the kind of consumer price subsidies that are the object of protests (Cheon, Urpelainen, \& Lackner, 2013; Victor, 2009). In energy-rich countries where state capacity to distribute resources is weak, consumer fuel subsidies tend to be common and resilient

\footnotetext{
${ }^{1}$ Henceforth we use the phrase 'fuel riots' since the vast majority of such riots are, at least superficially, about the price of fuel. For a detailed definition of fuel riots see (Natalini, Bravo, \& Newman, 2020)

${ }^{2}$ One exception is Natalini (2016) who examine the role of scarcity, prices and political fragility in driving food and fuel riots using a quantitative and agent-based modelling approach.
} 
to reform efforts (Inchauste \& Victor, 2017a). Authoritarian regimes are particularly likely to rely on such subsidy regimes as a source of popular legitimacy (Andresen, 2008; Rosser, 2006). Where other forms of social protection are limited, or natural resource wealth is highly concentrated, or where economic performance is poor, subsidies may be seen as part of the social contract (Lockwood, 2015). However, when such subsidies become unsustainable, governments often attempt to reduce them by raising fuel prices sharply (Rentschler \& Bazilian, 2017; Lockwood, 2015). When these adjustments result in large increases in the domestic price of oil, social discontent may rise, potentially increasing the likelihood of protests and riots.

Our paper also contributes to a smaller literature on the social and political effects of price subsidies. This literature is largely concerned with detailing the size of subsidies (Coady, Parry, Sears, \& Shang, 2017), the distributional impact of subsidies (Granado, Coady, \& Gillingham, 2010), the impact of subsidies on economic and environmental performance (Rentschler, Kornejew, \& Bazilian, 2017; Erickson et al., 2020), and the impact of subsidy reforms on the poor, among other groups. There is also a growing literature on the political economy of fossil fuel subsidy reform (Inchauste \& Victor, 2017b; Skovgaard \& van Asselt, 2018), which provides a nuanced understanding of the complexities of policy reform and why so little progress has been made on reform (Ross, Hazlett, \& Mahdavi, 2017). However, this literature rarely mentions an association between price subsidies and fuel riots, other than as an explanation of why reforms stop or stall, or as a reason why reforms are not attempted in the first place.

The paper proceeds as follows. Section 2 describes the data we use in the paper and brief descriptive statistics. Section 3 discusses the main results including an the analysis of price regimes as potential mediators of the relationship between fuel prices and riots; we also present some robustness tests. Section 4 examines why countries fix prices and create subsidies. Section 5 concludes.

\section{Data and descriptive statistics}

The data we use in this paper to measure the occurrence of fuel riots comes from the database published in Natalini et al. (2020), which spans the time-frame 2005-2016. We have updated the database until the year 2018 using the same methodology implemented by the authors.

The definition and data we use in this paper to measure the occurrence of fuel riots comes from Natalini et al. (2020). Fuel riots have been defined by the authors as 'incidents of significant unrest - riots, demonstrations, major protests - where grievances over fuel prices, the prospective removal of subsidies, or fuel availability were specifically identified as a factor which motivated people involved in the violent event' (Natalini et al., 2020). The original database spanned the time-frame 2005-2016 and was here updated until the year 2018 using the same methodology implemented by the authors. In particular, we performed a manual google search with a set of keywords to identify events that matched our definition of fuel riots. Although more sophisticated event collection methodologies exist (e.g. machine learning), these tend to be extremely time-consuming and often result in a large number of duplicates (e.g. via news feed repositories such as Lexis Nexis), and therefore a manual approach was preferred (see Newman (2020) for a comprehensive discussion on challenges with automatised event data collection with the example of food ri- 
ots). The keywords included different combinations and declinations of the words fuel/energy, violence, riot/protest and for every combination we reviewed the first ten pages of results. The search was global in scope and only included English online newspapers (or translated). Our data could therefore suffer from different types of biases (e.g. towards larger, more important events) that are very common when performing global-level research such as in our case and difficult to avoid (Dowd, Justino, Kishi, \& Marchais, 2020). The full database is included as an Appendix with references to the articles. These data were recorded on a monthly basis and transformed into a binary variable for whether the country had a fuel riot during the year/month or not. ${ }^{3}$

Figure 1 shows the geographical distribution of fuel riots over the period.

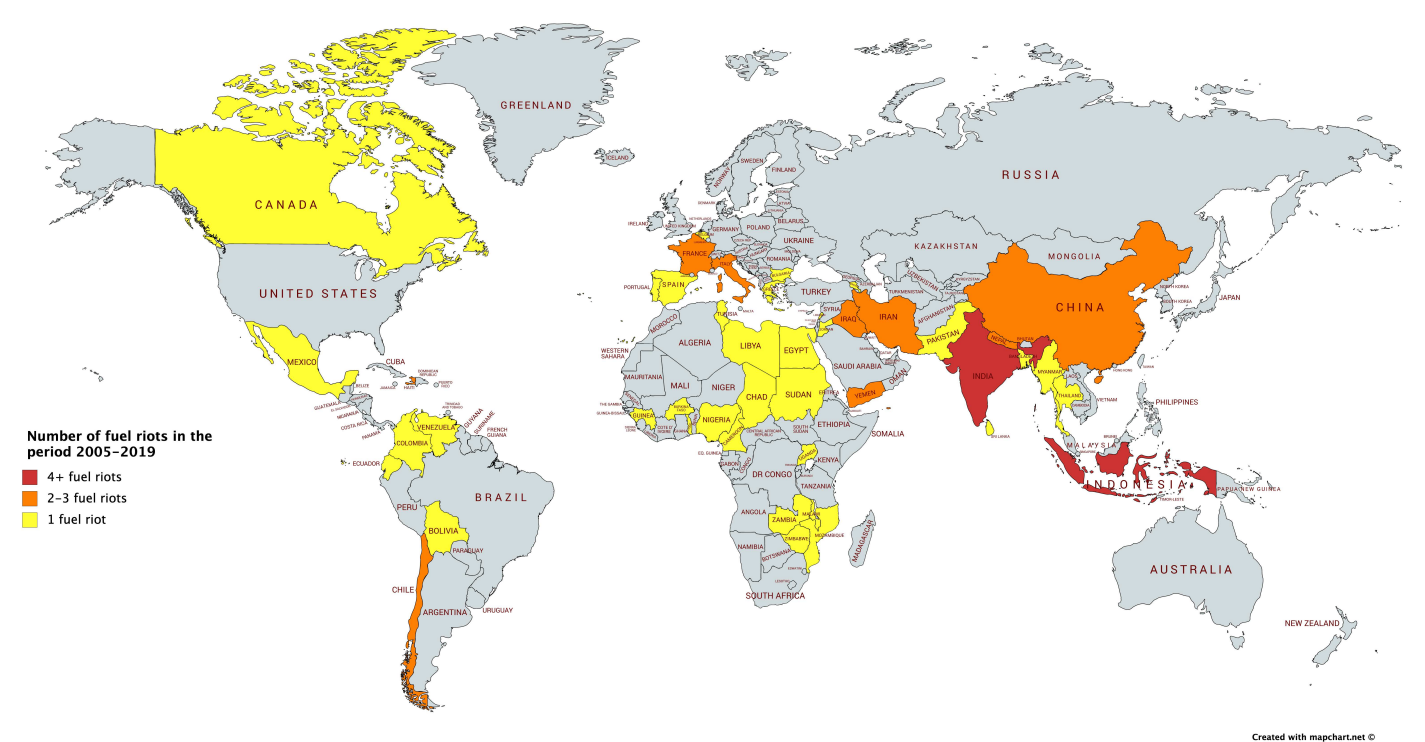

Figure 1: Map of incidence of fuel riots 2005-2018

Between 2005 and 2018, we observe 59 country-years in which fuel riots occurred. These are rare events since there are 3011 country-years in our data. However, fuel riots happen in quite a few countries: 41 of the 217 countries or jurisdictions in our dataset experienced a fuel riot over the period. Some countries experienced several fuel riots in that period: India had seven; Indonesia had five; and China and Yemen both had three.

Our main independent variables are the international price of oil, the level of fuel subsidies, and the domestic price regime implemented in each country. Average international prices for crude oil were sourced from the World Bank's Commodity Price Database. ${ }^{4}$ The data on fossil fuel subsidies comes from the IMF's calculation of subsidies for the period 2010-2017. We use estimates for 'total consumer pre-tax subsidies', which include four energy sources (oil, natural gas, coal and electricity)

\footnotetext{
${ }^{3}$ Doing so loses very little information in the annual data because there were only two countries that had more than one fuel riot in the same year - India in 2010 and Indonesia in 2013.

${ }^{4}$ The Pink Sheet - see https://www.worldbank.org/en/research/commodity-markets for details.
} 
as these capture the difference between retail prices and international price of the resource when this is internationally traded (i.e. fuel), and the difference between the retail price and the user cost (cost of production) for those not usually traded (i.e. electricity) (Coady et al., 2017). Our data on the domestic price regime is drawn from an analysis of the linkage between fuel riots and monthly price changes. This draws on the dataset of international and domestic gasoline prices compiled by Ross et al. (2017) which contains information about local retail gasoline prices for 157 countries from 2003 to 2015.

Globally, fuel riots are clearly related to the price of oil. Figure 2 shows the number of fuel riots that took place globally for each year from 2005 to 2018 alongside the international oil price: as expected, fuel riots spike when international oil prices spike, since this generally has a direct impact on the domestic price of fuel.

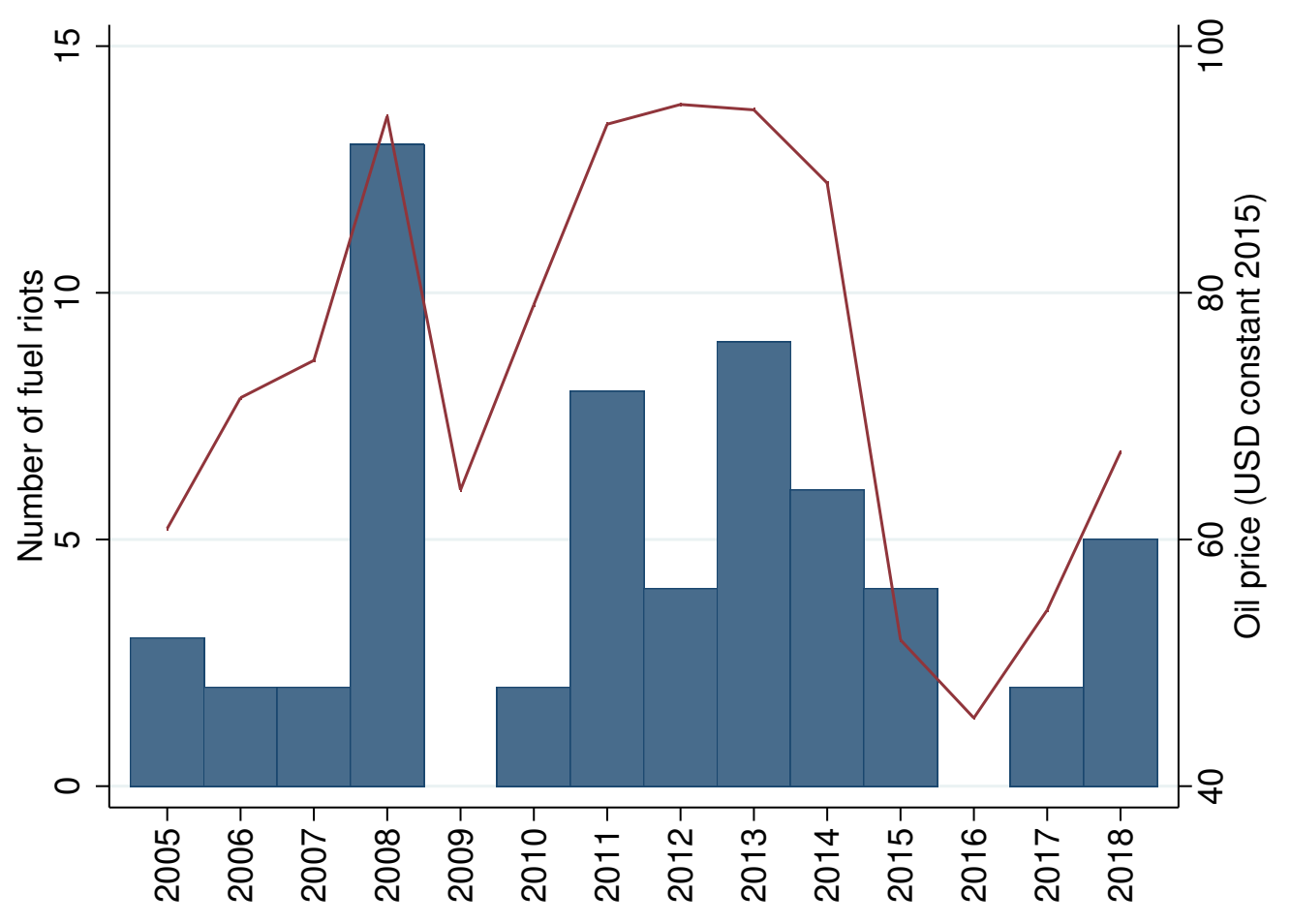

Figure 2: Fuel riots and international oil prices

The empirical analysis in the next section uses, in addition, a number of control variables since there are several other observable variables that may affect the propensity of riots. Since Gurr (1970), a large literature has shown how relative deprivation and drops in economic standing may give rise to social discontent and grievances. ${ }^{5}$ Therefore, it is reasonable to expect the number of fuel riots to be associated with the general development of the country. Mass protests may also be more likely when there is space for civic engagement, independent media, and

\footnotetext{
${ }^{5}$ See the review of this literature in Justino and Martorano (2019).
} 
organizations capable of mobilizing support are present (Tilly \& Tarrow, 2015). In addition, our fuel riots variable measures whether there has been a violent riot related to fuel during that year, which makes it more likely that we will observe fuel riots in countries with larger populations, simply because there are more people that might feel sufficiently unhappy to participate in a riot. We include in the main regressions country-level GDP and population as controls using data compiled from the World Bank's World Development Indicators (WDI) database.

\section{Results}

\subsection{Domestic price changes and fuel riots}

Our empirical strategy exploits the panel nature of our datasets to eliminate the possibility that the associations we observe are due to unobserved fixed characteristics of the country, or common time effects. Specifically, we estimate a fixed effects panel regression of the propensity for a fuel riot against the growth in domestic and international fuel prices. We control for the possibility of common time effects (notably changes in the international oil prices) using month dummies for the entire period. By including country fixed effects, we eliminate the possibility that any observed association is due to fixed country characteristics that might affect the likelihood of a fuel riot. We also include the log of per capita GDP and the log of population as controls. The model that we estimate is:

$$
\operatorname{Riot}_{i m}=\Delta p_{i m}^{d o m}+\Delta p_{i m}^{i n t}+\ln G D P p c_{i y}+\ln P o p_{i y}+\gamma m+\lambda i+\epsilon_{i t}
$$

where Riot $_{i m}$ indicates that country $i$ had a riot in month $m ; \Delta p_{i m}^{d o m}$ is the proportionate change in the domestic fuel price in the preceding month; $\Delta p_{i m}^{i n t}$ is the proportionate change in the international fuel price in the preceding month; $\ln G D P p c_{i y}$ is $\log$ GDP per capita; $\operatorname{lnPop}_{i y}$ is log of the population; $\gamma m$ is a month dummy; $\lambda i$ is the country fixed effect; and $\epsilon_{i t}$ represents a random error term.

Table 1 shows that there is a strong and statistically significant positive relationship between domestic price growth from month to month and fuel riots. The estimated coefficient suggests that an increase in the growth rate of local prices of, say 10 percentage points, would roughly quadruple the (initially low) probability of a fuel riot. However, the relationship with international fuel prices is much weaker and not statistically significant, even if domestic price changes are omitted, suggesting that riots are driven more by the way in which domestic prices are determined than by international price fluctuations.

\subsection{The role of price regimes}

We hypothesized in the introduction to the paper that the effect of fuel prices on fuel riots discussed above may be affected by price regimes. To analyze this mechanism, we proceed in three steps. First, we estimate the effect of changes in international prices on domestic prices to check how international price shocks may be transmitted to local markets. Second, we test whether fixing domestic prices - which effectively results in price subsidies on fuel - may cushion domestic prices against international price changes. Finally, we estimate the effect of such price subsidies on fuel riots. 
Table 1: Fuel riots and price changes

\begin{tabular}{lccc}
\hline & $\begin{array}{c}(1) \\
\text { Fuel_riot }\end{array}$ & $\begin{array}{c}(2) \\
\text { Fuel_riot }\end{array}$ & $\begin{array}{c}(3) \\
\text { Fuel_riot }\end{array}$ \\
\hline Growth of domestic gasoline price & $\begin{array}{c}0.0459^{* * *} \\
(7.11)\end{array}$ & $\begin{array}{c}0.0441^{* * *} \\
(6.98)\end{array}$ & \\
Growth of world gasoline price & 0.00855 & & 0.0124 \\
& $(0.47)$ & & $(0.68)$ \\
Log GDP per capita & -0.00196 & -0.00303 & -0.00285 \\
& $(-0.38)$ & $(-0.61)$ & $(-0.55)$ \\
Log population & -0.00129 & -0.00112 & -0.00134 \\
& $(-0.16)$ & $(-0.14)$ & $(-0.17)$ \\
\hline Observations & 18307 & 18728 & 18307 \\
\hline$t$ statistics in parentheses & & & \\
Fixed effects regression with month dummies & & & \\
${ }^{*} p<0.1,{ }^{* *} p<0.05,{ }^{* * *} p<0.001$ & & &
\end{tabular}

As we have discussed, domestic fuel prices are likely to be largely driven by international price changes, but this relationship can be dampened somewhat by fixing prices domestically, at least for a while. To assess the extent as to which this is true, we need a measure of the extent to which prices are fixed. Unfortunately, we are unaware of any database that indicates the policy regime followed by all countries over time. However, it is possible to infer the policy regime by looking at the extent to which prices change. ${ }^{6}$ We therefore use the database of monthly domestic prices described above to construct a measure of price 'fixedness' which is simply the percentage of months that domestic fuel prices remained the same. If a country has a fixedness of zero, it has a completely flexible price regime in which prices change every month, while if it has a fixedness of 100 then its price regime is completely rigid with no changes in prices at all.

Of the 157 countries for which we have monthly domestic price data, 73 have regimes in which the price changes every month. By contrast, only two countries had no price changes at all over the period. All other countries kept prices fixed at least for some months. However, most let prices adjust regularly. Over three-quarters of the countries adjusted prices at least every two months, while only around a fifth of countries adjusted domestic prices infrequently. To simplify, we define a country as having a 'fixed price regime' if it keeps domestic prices the same more than 80 percent of the time across all months for which we have data. If the country fixes prices less than this, we define it as having a 'flexible price regime'.

To answer our question about the pass-through of international prices to the local market in each country, we estimate the following model:

\footnotetext{
${ }^{6}$ For the moment, we have assumed that the policy regime remains fixed over the period for which we have data.
} 


$$
g p_{i m}^{d o m}=\beta_{0} g p_{i m}^{i n t}+\beta_{1} g p_{i, m-1}^{i n t}+\beta_{2} g p_{i, m-2}^{i n t}+\epsilon_{i m}
$$

where $g p_{i m}^{d o m}$ is the growth of the domestic fuel price of country $i$ between month $m$ and the preceding month; $g p_{i m}^{i n t}$ is the growth in the international fuel price during the same period; $g p_{i, m-1}^{i n t}$ and $g p_{i, m-2}^{i n t}$ are the growth in international prices in the preceding months; and $\epsilon_{i m}$ represents a random error term.

Our model reflects the fact that international prices are unlikely to pass through immediately to domestic prices, but may do so with some lag. Thus $\beta_{0}$ represents the short-run pass-through of international prices, while the sum $\beta_{0}+\beta_{1}+\beta_{2}$ provides an estimate of the long-run pass-through of prices. Since countries have quite different approaches to regulating domestic prices, it is likely that the value of these coefficients will differ substantially by country. We therefore estimate this model separately for all countries. We find that - for the median country, the short-run pass through is around 0.1 - that is around 10 percent of the change in the international price is passed through to domestic markets in the same month; the long-run (3 month) pass through is around 0.3 .

Our hypothesis is that a policy of fixing local prices should reduce the pass through of international prices. Figure 3 shows the range of estimates of short-run and long-run pass through coefficients for countries with flexible and fixed price regimes. As anticipated both short-run and long-run pass through coefficients in fixed price regime countries are significantly below those in countries with a flexible price regimes. The median short-run pass through for countries with flexible price regimes is 0.12 and the median long-run pass through is 0.33 ; however, for countries with fixed price regimes the equivalent figures are 0.005 and 0.08 . As one might expect, countries which fix prices most of the time pass through international price shocks much less.

However, while fixing prices does appear to reduce domestic price volatility in the short term, it also has a major impact on the size of domestic price increases when they do occur. Figure 4 shows the mean price change for the months in which price changes occurred for all countries plotted against the extent to which they fix prices. Countries that adjusted prices frequently (low fixedness), tended to have relatively small adjustments. However, those that fixed prices and held them for longer, tended to have much larger price increases when prices did change.

Dividing countries again into flexible and fixed price regimes as above, we find that the mean price change for countries with flexible price regimes was 0.7 percent (the standard deviation of price changes was also 0.7); but for fixed price regimes, the mean price change was 17.3 percent, almost 24 times larger. The standard deviation of price changes was 27, almost 40 times larger. Even if we include all of the months in which there is no change in price in the calculation of the mean price change and standard deviation, the mean price change for fixed price regimes is 68 percent higher than that of flexible price regimes and the standard deviation more than doubles. In short, fixed price regimes may protect populations from international price changes over the relatively short term, but when price changes do happen, they are much larger.

Why does fixing prices result in large domestic price shocks? The discussion in the introduction to the paper suggests that this is because countries that fix prices tend to have larger subsidies. When such subsidies become fiscally unsustainable, governments choose to raise the domestic price. If this is true, we would expect to 


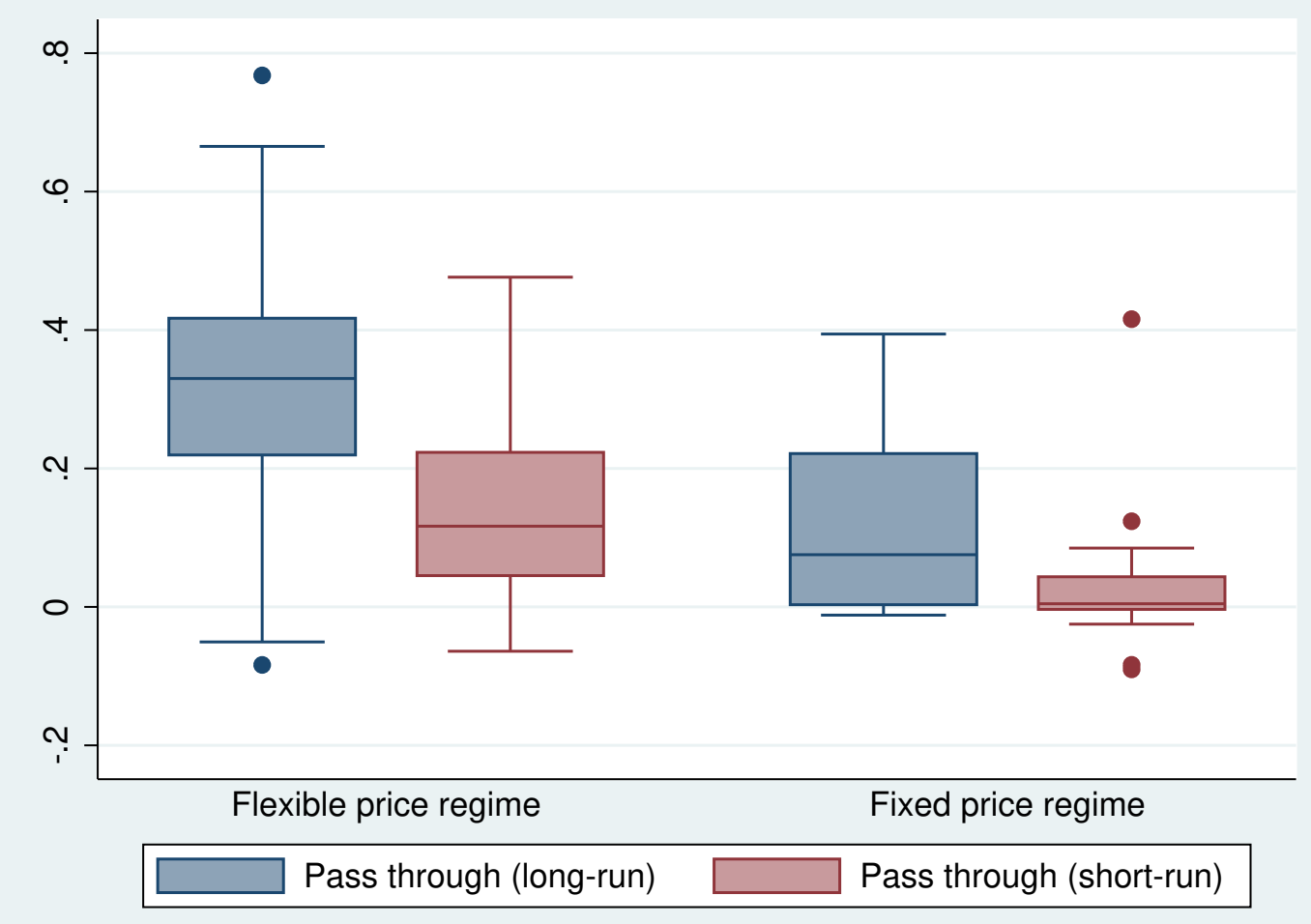

Figure 3: Pass through of international prices under flexible and fixed price regimes 


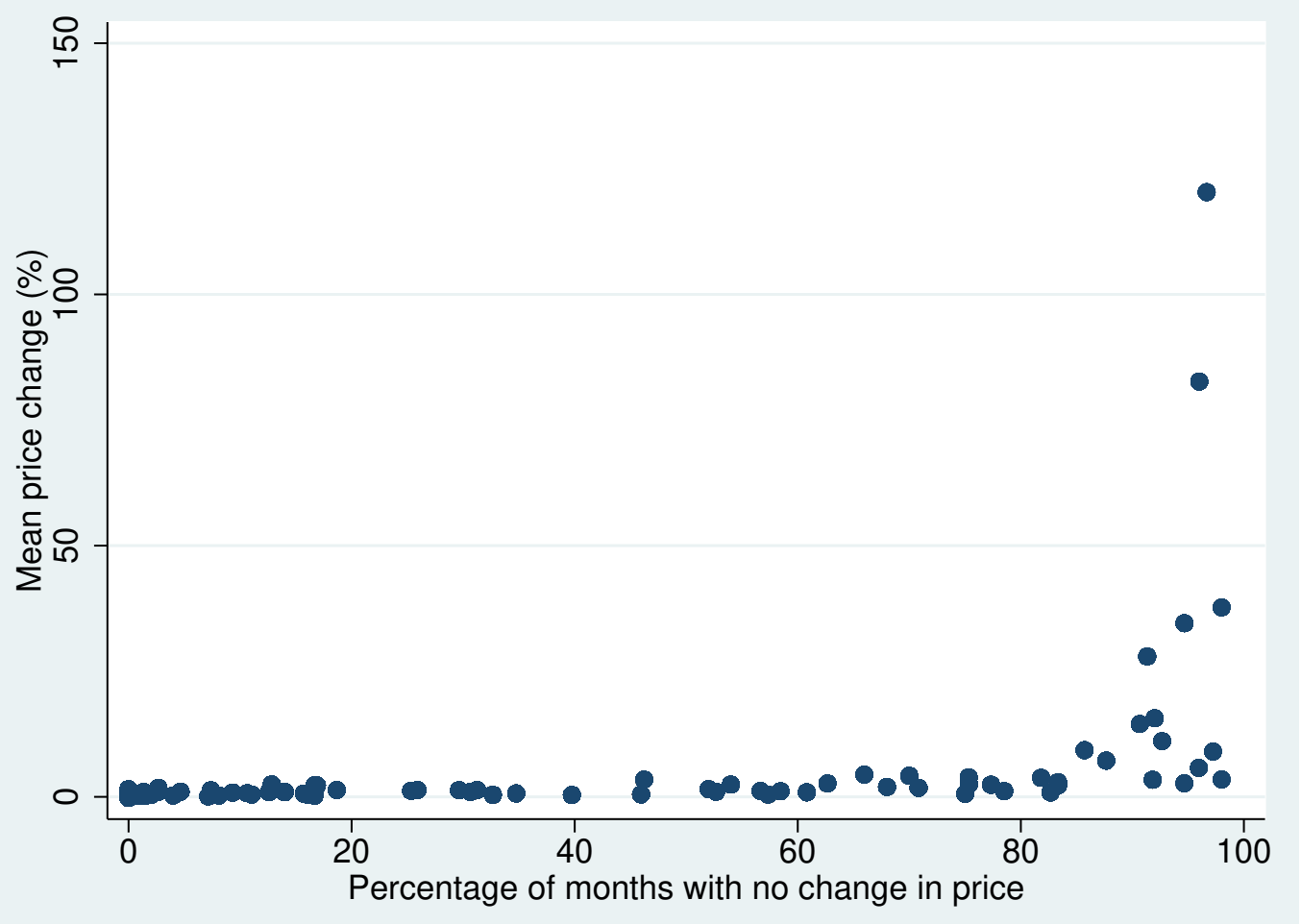

Figure 4: The impact of fixed prices on average price changes 
find evidence of a strong relationship between fixing prices and subsidies. To test this, we use annual data on subsidies for all countries. To see the impact of fixing domestic prices on subsidies, we regress subsidies on international oil prices and our measure of price fixedness. Table 2 shows that, as expected, higher oil prices make subsidies larger - but fixing domestic prices also increases subsidies significantly. ${ }^{7}$

Table 2: Subsidies, oil prices and fixed price regimes

\begin{tabular}{lc}
\hline & $(1)$ \\
& Log subsidies \\
\hline Log of real oil price & $0.271^{* * *}$ \\
& $(9.23)$ \\
Interaction of oil price and price fixedness & $0.0151^{* *}$ \\
& $(2.16)$ \\
Log GDP per capita & 0.00634 \\
& $(0.07)$ \\
Log population & $0.464^{* *}$ \\
& $(2.57)$ \\
\hline Observations & 922 \\
\hline$t$ statistics in parentheses & \\
Panel regression with country level fixed effects & \\
${ }^{*} p<0.1,{ }^{* *} p<0.05,{ }^{* * *} p<0.001$ &
\end{tabular}

Finally, we are now able to test the effect price regimes on fuel riots. We have established a connection between local price shocks and fuel riots. However, the evidence above suggests that fixing prices tends to lead to large subsidies, which adds to the fiscal pressure for a price adjustment. Reducing or removing such subsidies may abrogate a social contract which could lead to violent protest. If this is the case, we would expect to see that subsidies have an independent impact on the likelihood of fuel riots. Table 3 shows that this is indeed the case. Regressing fuel riots against domestic price changes and lagged subsidies shows that subsidies have a large and statistically significant impact on the likelihood of a fuel riot. ${ }^{8}$

Taken together, these results strongly suggest that fuel riots are driven by changes in fuel prices but these are mediated by the price regimes in place in each country. Fuel riots are more likely in countries with large implicit price subsidies that are not capable of maintaining them when faced with large increases in international oil prices.

\footnotetext{
${ }^{7}$ Again, we control for country level fixed effects which might influence the size of subsidies. We also include controls for time-varying factors which could influence the size of subsidies, notably GDP per capita and population.

${ }^{8}$ Since we are now using annual data, we take the largest monthly price change during the year as our domestic price change variable.
} 
Table 3: Riots and subsidies

(1)

Fuel riot

\begin{tabular}{lc}
\hline Max monthly growth of domestic gasoline price & $\begin{array}{c}0.182^{* * *} \\
(3.32)\end{array}$ \\
L.Log subsidies & $0.146^{* *}$ \\
& $(2.85)$ \\
Log GDP per capita & -0.199 \\
& $(-1.45)$ \\
Log population & -0.428 \\
& $(-1.23)$ \\
\hline Observations & 768 \\
\hline$t$ statistics in parentheses & \\
Panel regression with country level fixed effects and year dummies \\
${ }^{*} p<0.1,{ }^{* *} p<0.05,{ }^{* * *} p<0.001$
\end{tabular}

\subsection{Robustness tests}

To assess the robustness of our result that subsidies are associated with fuel riots we take three approaches. First, although we have already controlled for country and year fixed effects, and for GDP per capita and population, it is possible that there might be other, time-varying country characteristics that might give rise to fuel riots which are correlated with subsidies. In particular, political characteristics change over time and such changes could give rise to riots and might plausibly also be correlated with subsidies. We therefore draw on the Varieties of Democracy (VDEM) (Coppedge et al., 2019) and the Polity IV datasets (Marshall, 2019) which provide a comprehensive set of variables measuring different aspects of the political makeup of each country over time. We look at three measures: regime type; corruption; and civil society repression.

Annex Table 1 shows the same regression as Table 3 except each regression includes an additional political variable. In the first column we include regime type. ${ }^{9}$ The results suggest that more democratic regimes do have fewer fuel riots - but the size and significance of the coefficient on subsidies remains the same. In the second column we use an alternative measure for regime time - polity2 from the Polity IV dataset. ${ }^{10}$ Contrary to the VDEM regime variable, we find no statistically significant effect of the polity2 variable on fuel riots; but the coefficient on subsidies remains sizeable and significant. Column 3 considers the possibility that it might be perceptions of corruption, rather than type of regime, that affects riots. Citizens might be angry about corruption, which is also correlated with subsidies, leading to riots. However, we find no statistically significant effect of corruption on fuel riots,

\footnotetext{
${ }^{9}$ This takes the values: 0-autocracy; 1-electoral autocracy; 2-electoral democracy; 3-liberal democracy. See Coppedge et al. (2019) for details.

${ }^{10}$ Polity2 is a scale from -10 (strongly autocratic) to +10 (strongly democratic).
} 
while the coefficient on subsidies remains much the same. Finally, we consider the impact of civil society freedom. We would expect this to increase fuel riots and so it is possible that the effect of subsidies could simply be reflecting a correlation with a lack of civil society freedom. However, Column 4 shows that, the coefficient is not statistically significant and has no influence on the size of the subsidies coefficient.

Second, we examine the possibility that our dependent variable may be biased. Our dependent variable is based on media reports of violence associated with fuel related protests, but what constitutes violence is a subjective matter. We therefore draw on a separate database constructed for the Global Chaos Mapping Project ${ }^{11}$ which uses a narrower, but more precise, measure that records fuel related protests that led to at least one death. Annex Table 2 shows the same set of regressions as Annex Table 1, but using the new dependent variable. Although the coefficient on subsidies is smaller, it remains positive and statistically significant throughout.

Finally, we test the robustness of our results to the estimation method used. Annex Table 3 shows our original regression from Table 3, alongside estimations of the same regression using a panel logit specification, as well as a Probit with country dummies. In both cases, the results confirm a strong and statistically significant association between subsidies and fuelriots.

\section{Why countries fix prices and create subsidies}

Finally, given the damaging impact of fixing domestic prices and thereby creating fuel subsidies, as well as their propensity to prompt riots, we explore why so many governments use this policy instrument. The literature points towards two possible motivations for adopting subsidies by fixing prices. First, people living in countries with oil may feel that they are entitled to a share of the benefits. Knowing this, states choose to subsidize fuel as a way of providing a benefit to the population that is directly linked to the resource (McCulloch, Moerenhout, \& Yang, 2020). In a sense, this is a basic social contract, but one not based on service delivery, but rather simply sharing out, in an easy and conspicuous way, some of the proceeds of oil wealth. If this is the case, we would expect the adoption of a fixed price regime to be strongly associated with being a net energy exporter.

Second, Victor (2009) argues that some countries subsidize fuel because they lack the capacity to implement more sophisticated forms of social protection. If this is the case, we would expect to see a negative association between government effectiveness and the size of subsidies.

We separately regress the size of subsidies and whether a country has a fixed price regime against whether the country is a net energy exporter and measures of government effectiveness. ${ }^{12}$

Table 4 and Table 5 show that the data support both of the hypotheses above. Net energy exporters are much more likely to adopt a fixed price regime and much more likely to have large subsidies. Similarly, countries with more effective administration are much less likely to adopt such policies. However, we find that several

\footnotetext{
${ }^{11}$ See https://aru.ac.uk/global-sustainability-institute-gsi/research/global-risk-and-resilience/globalchaos-map-project for details

${ }^{12}$ We cannot use a fixed effects panel regression because whether a country is a net energy exporter is almost always a fixed characteristic; we therefore estimate an OLS regression controlling for heterogeneity with year and region dummies as well as GDP per capita and population as before.
} 
of our measures of governance quality are associated with subsidies. If we substitute our measure of government effectiveness with the measures described above for regime type, corruption, and civil society freedom, our results suggest that more democratic and less corrupt regimes, as well as those with greater civil society freedom, also tend to have fewer subsidies, while those with more corruption and less effective governments are more likely to adopt fixed price regimes. While we are not able to assert causality, our results are consistent with the hypotheses that such policies are often introduced in resource abundant countries with relatively weak governance.

Table 4: Structural determinants of subsidies

\begin{tabular}{lcccc}
\hline & $(1)$ & $(2)$ & $(3)$ & $(4)$ \\
& Log subsidies & Log subsidies & Log subsidies & Log subsidies \\
\hline Net energy exporter & $0.612^{* * *}$ & $0.632^{* * *}$ & $0.604^{* * *}$ & $0.552^{* * *}$ \\
& $(3.96)$ & $(4.24)$ & $(4.12)$ & $(3.51)$ \\
Government effectiveness & $-0.348^{* *}$ & & & \\
& $(-2.72)$ & & & \\
Regime type & & $-0.266^{* *}$ & & \\
Extent of corruption & & $(-3.28)$ & & \\
& & & & \\
Civil society freedom & & & & $-0.956^{* * *}$ \\
& & & & $(3.49)$ \\
Log GDP per capita & $0.215^{* *}$ & $0.103^{*}$ & $0.175^{* *}$ & 0.0956 \\
& $(2.25)$ & $(1.71)$ & $(2.44)$ & $(1.62)$ \\
Log population & $0.302^{* * *}$ & $0.316^{* * *}$ & $0.301^{* * *}$ & $0.302^{* * *}$ \\
& $(6.80)$ & $(7.03)$ & $(6.65)$ & $(6.77)$ \\
\hline Observations & 703 & 698 & 698 & 698 \\
\hline$t$ statistics in parentheses & & & \\
OLS regression with year and region dummies & & & \\
${ }^{*} p<0.1,{ }^{* *} p<0.05,{ }^{* * *} p<0.001$ & & &
\end{tabular}


Table 5: Structural determinants of fixing prices

\begin{tabular}{|c|c|c|c|c|}
\hline & $\begin{array}{c}(1) \\
\text { Fixed price regime }\end{array}$ & $\begin{array}{c}(2) \\
\text { Fixed price regime }\end{array}$ & $\begin{array}{c}(3) \\
\text { Fixed price regime }\end{array}$ & $\begin{array}{c}(4) \\
\text { Fixed price regime }\end{array}$ \\
\hline Net energy exporter & $\begin{array}{c}0.136^{* *} \\
(2.48)\end{array}$ & $\begin{array}{c}0.173^{* *} \\
(2.99)\end{array}$ & $\begin{array}{c}0.146^{* *} \\
(2.64)\end{array}$ & $\begin{array}{l}0.185^{* *} \\
(2.96)\end{array}$ \\
\hline Government effectiveness & $\begin{array}{c}-0.0981^{*} \\
(-1.70)\end{array}$ & & & \\
\hline Regime type & & $\begin{array}{r}-0.0191 \\
(-0.47)\end{array}$ & & \\
\hline Extent of corruption & & & $\begin{array}{l}0.220^{*} \\
(1.75)\end{array}$ & \\
\hline Civil society freedom & & & & $\begin{array}{c}0.00102 \\
(0.04)\end{array}$ \\
\hline Log GDP per capita & $\begin{array}{c}0.0213 \\
(0.48)\end{array}$ & $\begin{array}{c}-0.0302 \\
(-1.01)\end{array}$ & $\begin{array}{c}0.00296 \\
(0.09)\end{array}$ & $\begin{array}{c}-0.0383 \\
(-1.57)\end{array}$ \\
\hline Log population & $\begin{array}{c}0.00720 \\
(0.48)\end{array}$ & $\begin{array}{c}0.00855 \\
(0.56)\end{array}$ & $\begin{array}{c}0.00638 \\
(0.42)\end{array}$ & $\begin{array}{c}0.00860 \\
(0.54)\end{array}$ \\
\hline Observations & 1305 & 1305 & 1305 & 1305 \\
\hline
\end{tabular}




\section{Conclusions}

Fuel riots are common and can have major implications for ordinary people and for entire countries. They are violent - often leading to deaths - and are highly disruptive. Moreover, fuel riots often pre-empt or prevent further attempts at policy dialogue and reform - at least for a while (Hossain, 2020).

Our findings suggest that fuel riots are primarily driven by domestic price increases. To some extent, these reflect changes in the international oil price, but these effects are mediated by how countries attempt to protect their populations by fixing domestic prices for periods of time. However, fixed price policies tend to result in large fuel subsidies which can create fiscal strains. Our results show that large fuel subsidies may make fuel riots more likely. This is because when these subsidies are no longer sustainable, the resulting price increases are much larger than those that typically occur in countries with more flexible price regimes, potentially triggering riots.

We also find that net countries which are energy exporters are much more likely to fix prices and more likely to have large subsidies as a result. Countries will low levels of government capability and effectiveness are also more likely to have large subsidies, supporting the idea that subsidies are used as an administratively easy way of providing a social transfer. Ironically, we find that the large subsidies that such policies produce do not protect populations from price shocks and make fuel riots more likely.

Our findings further emphasize the value of removing fuel subsidies and shifting to flexible price regimes. However, this naturally begs the question of why countries have not already done so. The answer is likely to lie in the complex politics of social contracts in energy net exporter countries. Nonetheless, our results should give policymakers further pause for thought about the wisdom of policies that perpetuate large subsidies. Subsidies may provide short-term political gains but, by making riots more likely, they may have large long-term political costs. Going forward, researchers may wish to focus more on building a better understanding of the political, and not just the economic, dimensions of subsidy reform.

\section{Data availability statement}

The authors declare that the data supporting the findings of this study are available within the paper and its supplementary information files.

\section{Code availablility statement}

The authors declare that the Stata do files used to undertake the analysis are included in the supplementary information files.

\section{References}

Andresen, N. A. (2008). Public choice theory, semi-authoritarian regimes and energy prices: A preliminary report. Fridtjof Nansen Institute, the Norwegian Institute for International Affairs and Econ Pöyry, RUSSCASP project. Working Paper, 10. 
Blair, G., Christensen, D., \& Rudkin, A. (2020). Do Commodity Price Shocks Cause Armed Conflict? A Meta-Analysis of Natural Experiment (ESOC Working Paper No. 21). Princeton University. Retrieved from http://esoc.princeton.edu/wp21.

Carbonnier, G., \& Wagner, N. (2011). Oil, gas and minerals: The impact of resource-dependence and governance on sustainable development.

Cheon, A., Urpelainen, J., \& Lackner, M. (2013). Why do governments subsidize gasoline consumption? an empirical analysis of global gasoline prices, 2002-2009. Energy Policy, 56, 382-390.

Coady, D., Parry, I., Sears, L., \& Shang, B. (2017, March). How Large Are Global Fossil Fuel Subsidies? World Development, 91, 11-27. Retrieved 2019-05-22, from http://www.sciencedirect.com/science/article/pii/S0305750X16304867 doi: $10.1016 /$ j.worlddev.2016.10.004

Coppedge, M., Gerring, J., Knutsen, C. H., Lindberg, S. I., Teorell, J., Altman, D., ... Ziblatt, D. (2019). V-Dem Codebook v9 (Tech. Rep.). V-DEM Institute, University of Gothenburg.

Dowd, C., Justino, P., Kishi, R., \& Marchais, G. (2020). Comparing 'new' and 'old' media for violence monitoring and crisis response: Evidence from kenya. Research \& Politics, 7(3), 2053168020937592. Retrieved from https://doi.org/10.1177/2053168020937592 doi: 10.1177/2053168020937592

Dube, O., \& Vargas, J. F. (2013). Commodity Price Shocks and Civil Conflict: Evidence from Colombia. The Review of Economic Studies, 80(4), 13841421. Retrieved from https://doi.org/10.1093/restud/rdt009 (_eprint: https://academic.oup.com/restud/article-pdf/80/4/1384/18384495/rdt009.pdf) doi: 10.1093/restud/rdt009

Erickson, P., van Asselt, H., Koplow, D., Lazarus, M., Newell, P., Oreskes, N., \& Supran, G. (2020, February). Why fossil fuel producer subsidies matter. Nature, 578(7793), E1-E4. Retrieved 2020-07-12, from http://www nature.com/articles/s41586-019-1920-x doi: 10.1038/s41586019-1920-x

Granado, J. A. d., Coady, D., \& Gillingham, R. (2010). The Unequal Benefits of Fuel Subsidies: A Review of Evidence for Developing Countries. IMF Working Paper, 202.

Gurr, T. R. (1970). Sources of rebellion in western societies: Some quantitative evidence. The Annals of the American Academy of Political and Social Science, 391 (1), 128-144.

Hossain, N. (2020). Demanding power - synthesis report (Tech. Rep.). Institute of Development Studies.

Inchauste, G., \& Victor, D. G. (Eds.). (2017a). The political economy of energy subsidy reform. Washington, D.C: World Bank Publications.

Inchauste, G., \& Victor, D. G. (Eds.). (2017b). The Political Economy of Energy Subsidy Reform. The World Bank. Retrieved 2017-03-30, from http://elibrary. worldbank.org/doi/book/10.1596/978-1-4648-1007-7 doi: 10.1596/978-1-4648-1007-7

Justino, P., \& Martorano, B. (2019). Redistributive Preferences and Protests in Latin America. Journal of Conflict Resolution, 63(9), 2128-2154. 
Lockwood, M. (2015). Fossil fuel subsidy reform, rent management and political fragmentation in developing countries. New Political Economy, 20(4), 475-494.

Marshall, M. G. (2019). Polity iv project: Dataset users' manual (Tech. Rep.). Center for Systemic Peace and Societal-Systems Research Inc.

McCulloch, N., Moerenhout, T., \& Yang, J. (2020). Fuel subsidy reform and the social contract in nigeria: a micro-economic analysis.

Natalini, D. (2016). Estimating the role of scarcity, prices and political fragility in food and fuel riots: a quantitative and agent-based modelling approach (doctoral, Anglia Ruskin University). Retrieved 2017-12-19, from http://arro.anglia.ac.uk/701893/

Natalini, D., Bravo, G., \& Newman, E. (2020). Fuel riots-definition, evidence and policy implications for a new type of energy-related conflict. , 147 (December). doi: https://doi.org/10.1016/j.enpol.2020.111885

Newman, E. (2020). Hungry, or hungry for change? food riots and political conflict, 2005-2015. Studies in Conflict \&3 Terrorism, 43(4), 300324. Retrieved from https://doi.org/10.1080/1057610X.2018.1454042 doi: 10.1080/1057610X.2018.1454042

Rentschler, J., \& Bazilian, M. (2017, October). Reforming fossil fuel subsidies: drivers, barriers and the state of progress. Climate Policy, 17(7), 891-914. Retrieved 2017-12-23, from https://doi.org/10.1080/14693062.2016.1169393 doi: 10.1080/14693062.2016.1169393

Rentschler, J., Kornejew, M., \& Bazilian, M. (2017). Fossil fuel subsidy reforms and their impacts on firms. Energy Policy, 108. doi: 10.1016/j.enpol.2017.06.036

Ross, M. L. (2004). What do we know about natural resources and civil war? Journal of Peace Research, 41(3), 337-356. Retrieved from http://www.jstor.org/stable/4149748

Ross, M. L., Hazlett, C., \& Mahdavi, P. (2017). Global progress and backsliding on gasoline taxes and subsidies. Nature Energy, 2(1), 16201.

Rosser, A. (2006). The political economy of the resource curse: A literature survey (Tech. Rep.). Brighton, Sussex: Institute of Development Studies.

Skovgaard, J., \& van Asselt, H. (2018). The Politics of Fossil Fuel Subsidies and Their Reform. Cambridge University Press.

Tilly, C., \& Tarrow, S. (2015). Politique (s) du conflit: De la grève à la révolution. $2 e$ édition augmentée d'une préface. Presses de sciences po.

Van der Ploeg, F. (2011). Natural resources: curse or blessing? Journal of Economic literature, 49(2), 366-420.

Victor, D. G. (2009). The politics of fossil-fuel subsidies. 


\section{Annex 1: Robustness tests}

Table 6: Robustness to political variables

\begin{tabular}{|c|c|c|c|c|}
\hline & $\begin{array}{c}(1) \\
\text { Fuel riot }\end{array}$ & $\begin{array}{c}(2) \\
\text { Fuel riot }\end{array}$ & $\begin{array}{c}(3) \\
\text { Fuel riot }\end{array}$ & $\begin{array}{c}(4) \\
\text { Fuel riot }\end{array}$ \\
\hline Max monthly growth of domestic gasoline price & $\begin{array}{c}0.180^{* *} \\
(3.28)\end{array}$ & $\begin{array}{c}0.179^{* *} \\
(3.19)\end{array}$ & $\begin{array}{c}0.183^{* * *} \\
(3.32)\end{array}$ & $\begin{array}{c}0.178^{* *} \\
(3.22)\end{array}$ \\
\hline L.Log subsidies & $\begin{array}{c}0.154^{* *} \\
(2.99)\end{array}$ & $\begin{array}{c}0.154^{* *} \\
(2.90)\end{array}$ & $\begin{array}{c}0.145^{* *} \\
(2.82)\end{array}$ & $\begin{array}{c}0.150^{* *} \\
(2.91)\end{array}$ \\
\hline Regime type & $\begin{array}{c}-0.0647^{* *} \\
(-2.01)\end{array}$ & & & \\
\hline Polity2 & & $\begin{array}{c}-0.00618 \\
(-0.70)\end{array}$ & & \\
\hline Extent of corruption & & & $\begin{array}{l}0.143 \\
(0.63)\end{array}$ & \\
\hline Civil society freedom & & & & $\begin{array}{r}-0.0257 \\
(-0.95)\end{array}$ \\
\hline Log GDP per capita & $\begin{array}{l}-0.161 \\
(-1.16)\end{array}$ & $\begin{array}{l}-0.203 \\
(-1.45)\end{array}$ & $\begin{array}{l}-0.196 \\
(-1.42)\end{array}$ & $\begin{array}{l}-0.185 \\
(-1.33)\end{array}$ \\
\hline Log population & $\begin{array}{l}-0.390 \\
(-1.12)\end{array}$ & $\begin{array}{l}-0.443 \\
(-1.23)\end{array}$ & $\begin{array}{l}-0.430 \\
(-1.23)\end{array}$ & $\begin{array}{l}-0.408 \\
(-1.17)\end{array}$ \\
\hline Observations & 763 & 750 & 763 & 763 \\
\hline
\end{tabular}

$t$ statistics in parentheses

Panel regression with country level fixed effects and year dummies

${ }^{*} p<0.1,{ }^{* *} p<0.05,{ }^{* * *} p<0.001$ 
Table 7: Robustness to alternative dependent variables

\begin{tabular}{lcccc}
\hline & $(1)$ & $(2)$ & $(3)$ & $(4)$ \\
& GCMP_fuel & GCMP_fuel & GCMP_fuel & GCMP_fuel \\
\hline Max monthly growth of domestic gasoline price & $0.149^{* * *}$ & $0.143^{* * *}$ & $0.151^{* * *}$ & $0.145^{* * *}$ \\
& $(4.49)$ & $(4.25)$ & $(4.52)$ & $(4.34)$ \\
L.Log subsidies & $0.0844^{* *}$ & $0.0934^{* *}$ & $0.0807^{* *}$ & $0.0860^{* *}$ \\
& $(2.72)$ & $(2.92)$ & $(2.60)$ & $(2.77)$ \\
Regime type & $-0.0325^{*}$ & & & \\
& $(-1.67)$ & & & \\
Polity2 & & $-0.0103^{*}$ & & \\
& & $(-1.94)$ & & $-0.0323^{* *}$ \\
Extent of corruption & & & $(-0.65)$ & $(-1.99)$ \\
& & & & \\
Civil society freedom & & & & \\
& & & & \\
Log GDP per capita & 0.0789 & 0.0583 & 0.0575 & $(0.92)$ \\
& $(0.94)$ & $(0.69)$ & $(0.69)$ & $-0.396^{*}$ \\
Log population & $-0.403^{*}$ & $-0.431^{* *}$ & $-0.423^{* *}$ & $(-1.88)$ \\
\hline Observations & $(-1.91)$ & $(-1.98)$ & $(-2.00)$ & 763 \\
\hline$t$ statistics in parentheses & 763 & 750 & 763 & \\
Panel regression with country level fixed effects and year dummies & & & & \\
$* 0.1,{ }^{* *} p<0.05,{ }^{* * *} p<0.001$ & & & & \\
\end{tabular}


Table 8: Robustness to estmation method

\begin{tabular}{lccc}
\hline & $(1)$ & $(2)$ & $(3)$ \\
& Fuel riot & Fuel riot & Fuel riot \\
\hline main & & & \\
Max monthly growth of domestic gasoline price & $0.182^{* * *}$ & 1.482 & 1.321 \\
& $(3.32)$ & $(1.25)$ & $(1.54)$ \\
L.Log subsidies & $0.146^{* *}$ & $4.073^{* *}$ & $3.291^{* *}$ \\
& $(2.85)$ & $(2.32)$ & $(2.74)$ \\
Log GDP per capita & -0.199 & -3.610 & -2.554 \\
& $(-1.45)$ & $(-0.83)$ & $(-0.88)$ \\
Log population & -0.428 & -15.45 & -10.93 \\
& $(-1.23)$ & $(-1.16)$ & $(-1.28)$ \\
\hline Observations & 768 & 124 & 124 \\
\hline
\end{tabular}

$t$ statistics in parentheses

(1) Panel regression with country level fixed effects and year dummies

(2) Panel logit with country level fixed effects and year dummies

(3) Probit with year and country dummies

${ }^{*} p<0.1,{ }^{* *} p<0.05,{ }^{* * *} p<0.001$ 


\section{Figures}

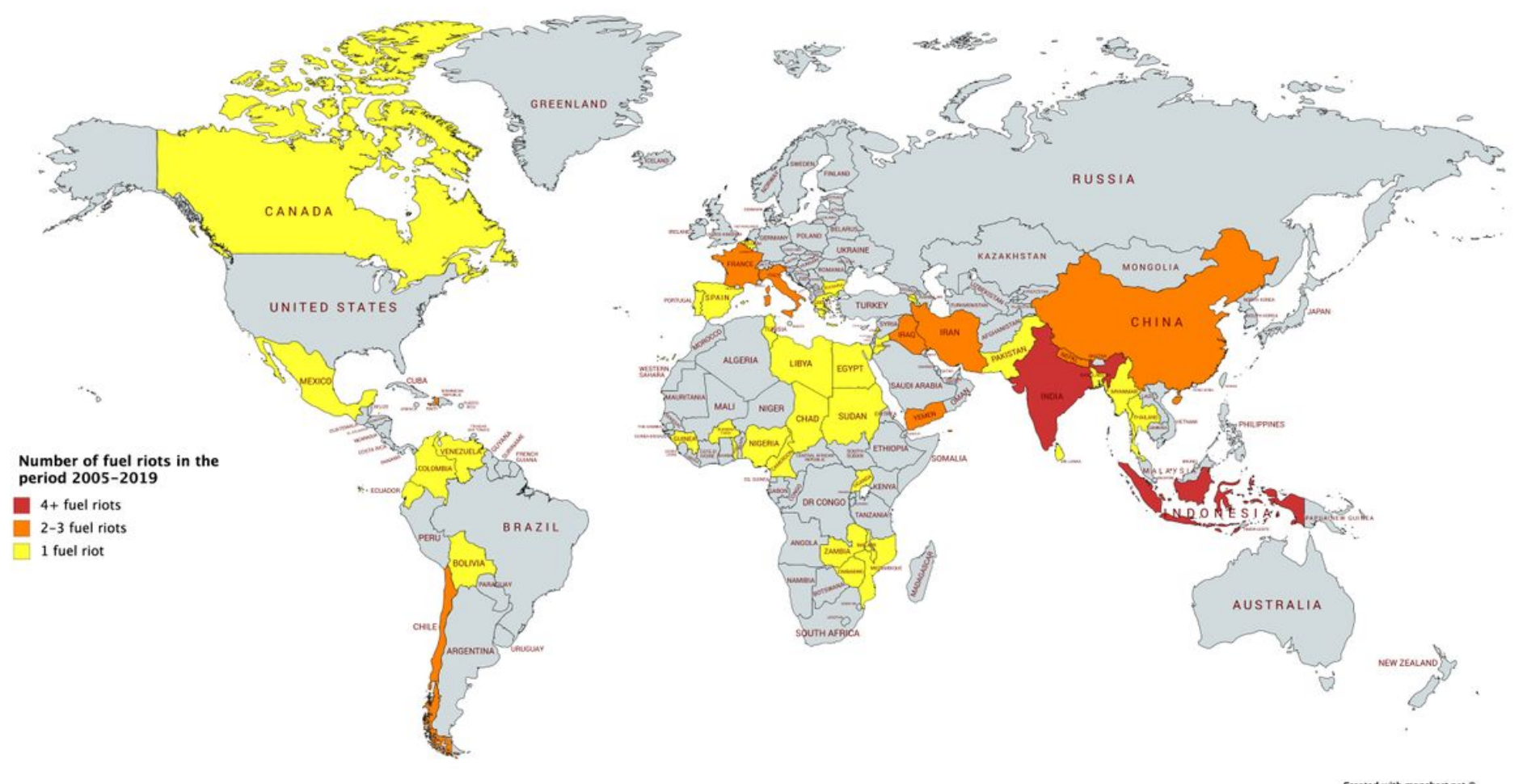

\section{Figure 1}

Map of incidence of fuel riots 2005-2018. Note: The designations employed and the presentation of the material on this map do not imply the expression of any opinion whatsoever on the part of Research Square concerning the legal status of any country, territory, city or area or of its authorities, or concerning the delimitation of its frontiers or boundaries. This map has been provided by the authors. 


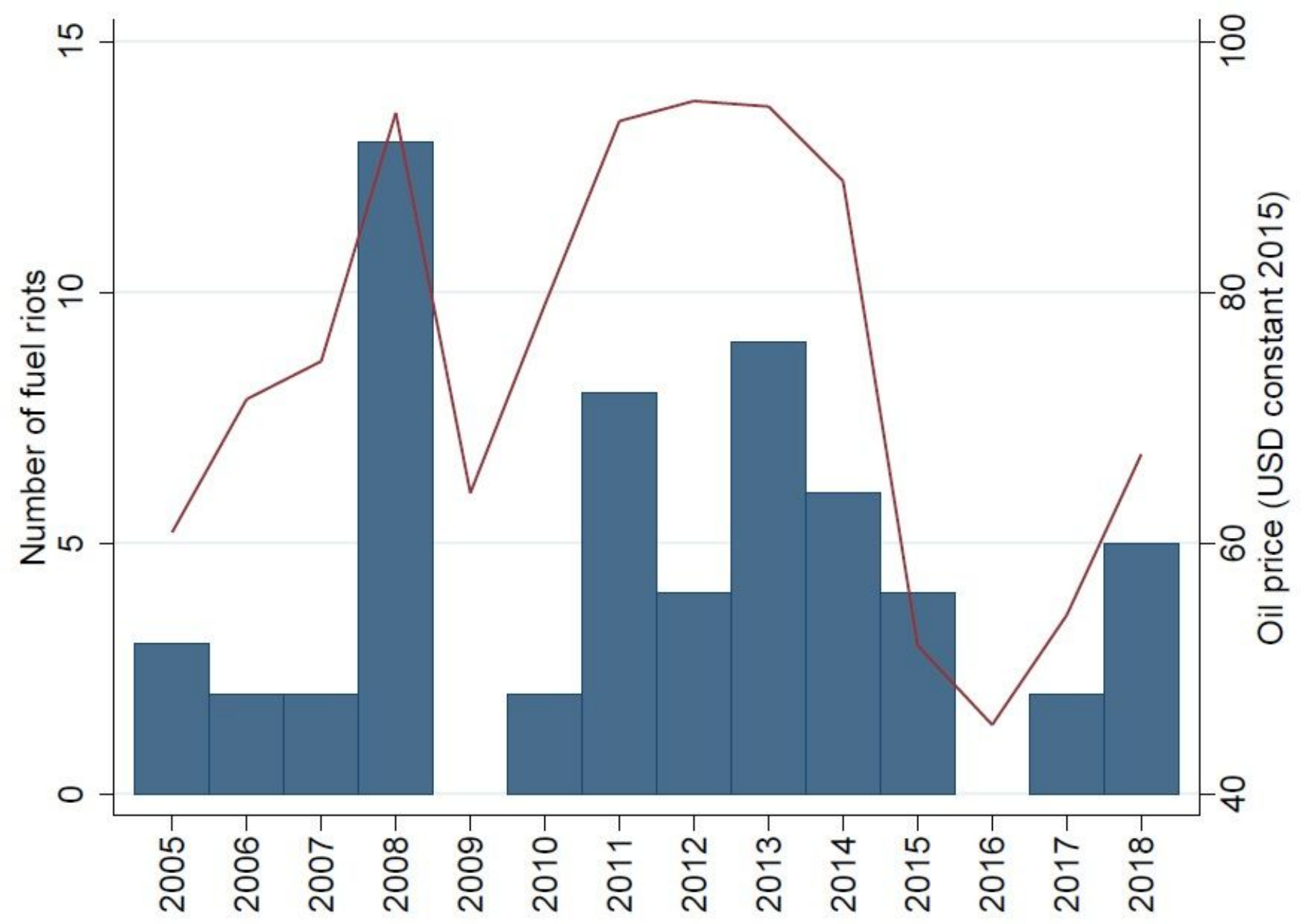

Figure 2

Fuel riots and international oil prices 


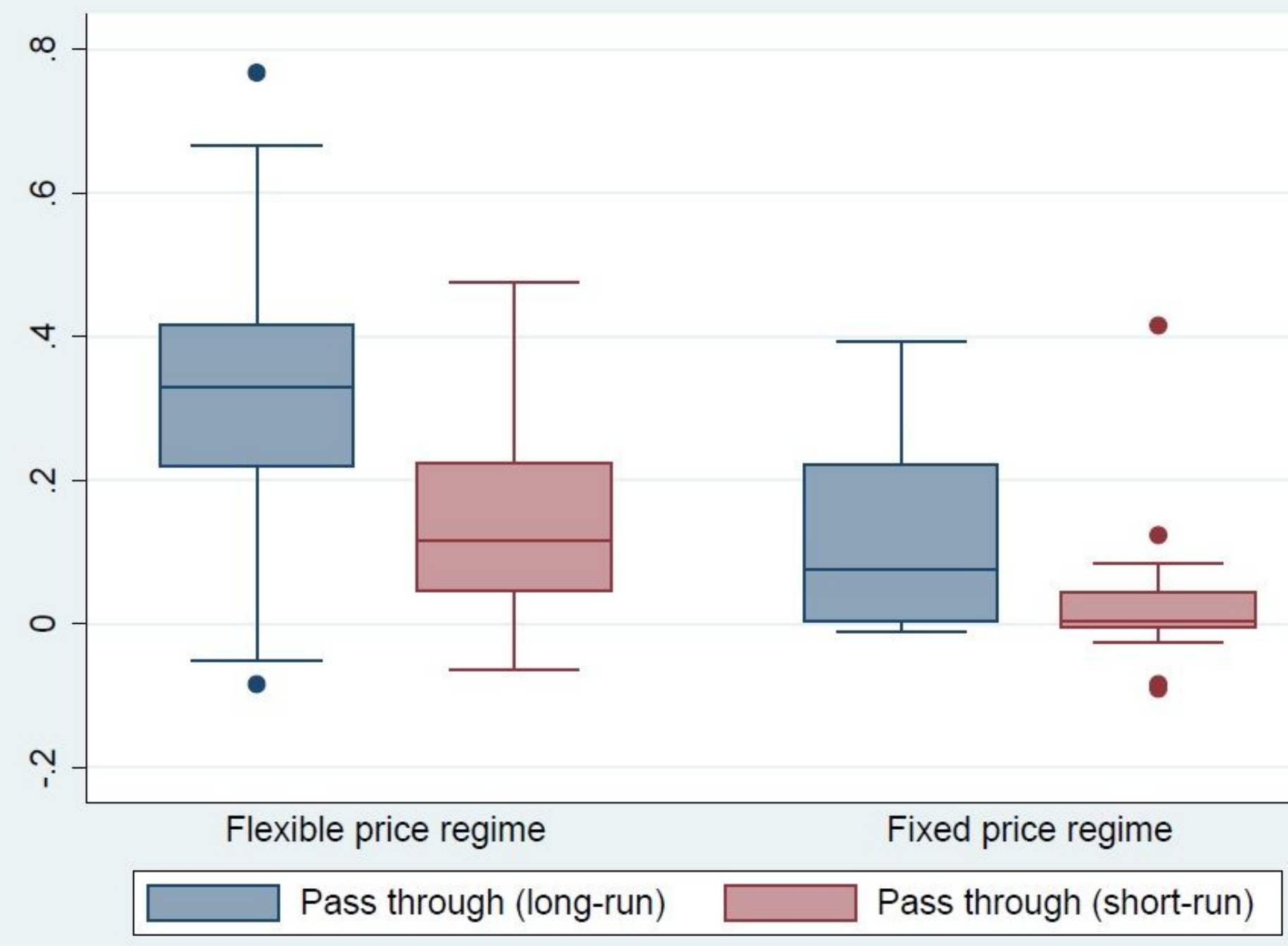

Figure 3

Pass through of international prices under flexible and fixed price regimes 


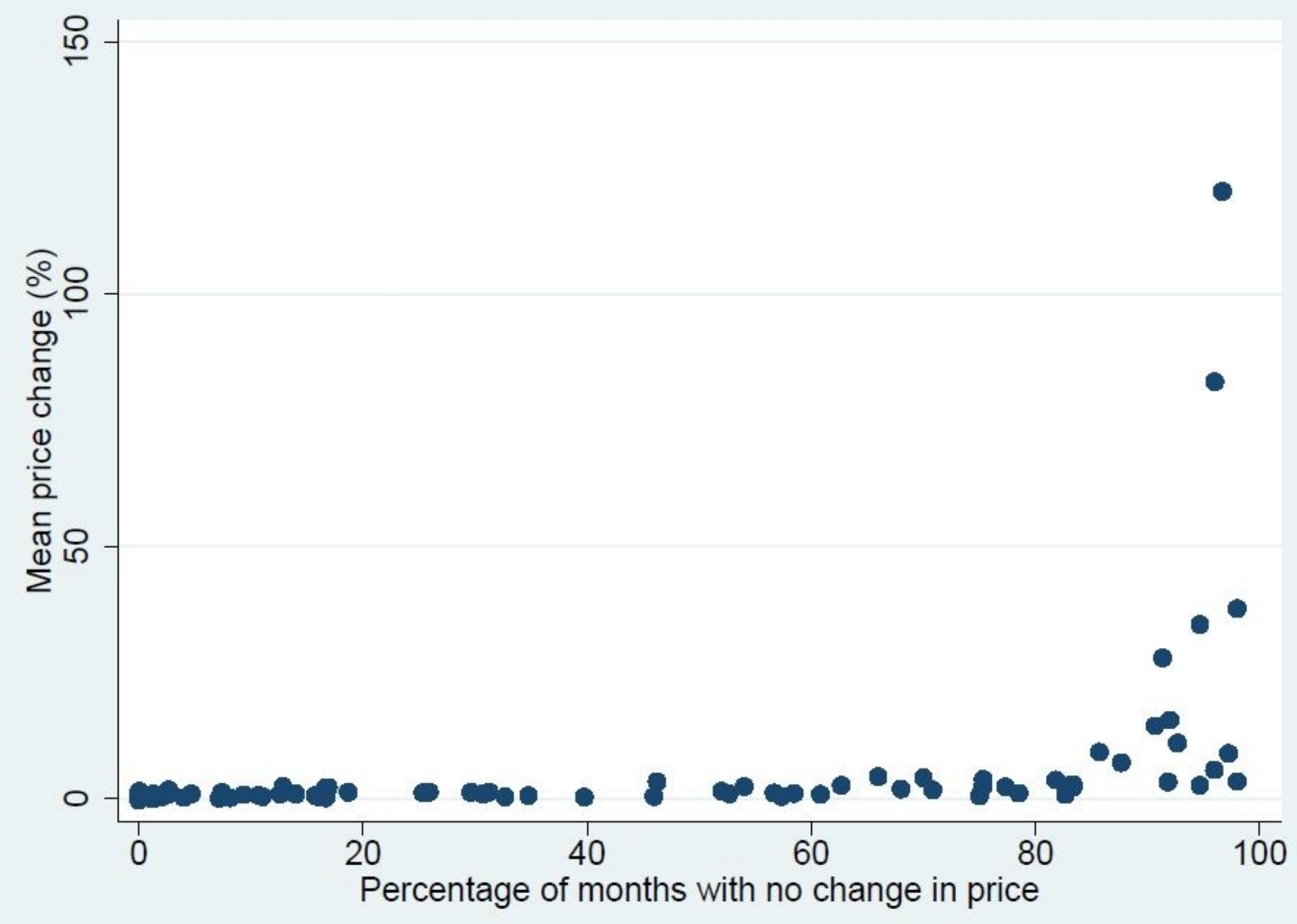

Figure 4

The impact of fixed prices on average price changes

\section{Supplementary Files}

This is a list of supplementary files associated with this preprint. Click to download.

- McCullochetal.SM.docx

- Databasev3.csv

- natalini.docx 